\title{
A PROPÓSITO DE UMA NOVA EDIÇÃO DAS MEMÓRIAS DE UM SARGENTO DE MILICIAS
}

Mamede Mustafa Jarouche *

RESUMO: Explicam-se, no presente artigo, os critérios de fixação textual de uma nova edição do livro Memórias de um Sargento de Milíias. Tratando-se, como é o caso, de um texto que conta apenas duas lições para cotejo - o "folhetim" e uma única edição em livro publicada durante a vida do autor -, procurou-se valorizar a publicação seriada, especialmente nas passagens em que a lição do livro pareceu duvidosa.

Palavras-chave: Memórias de um Sargento de Milícias, edição crítica, literatura romântica brasileira, folhetim, século dezenove, Manuel Antônio de Almeida.

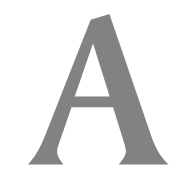

edição das Memórias de um Sargento de Milícias lançada pela Editora Ateliê obedeceu a alguns critérios que fogem aos padrões da coleção didática em que se insere, e que por isso não foram ali expostos. Assim, na leitura do presente artigo, deve-se levar em conta que ele pressupõe o conhecimento daquele trabalho, do qual é a justificativa.

O texto da Ateliê baseou-se, evidentemente, no da primeira edição de 1854-1855, a única publicada em vida do autor, cotejada com o texto parceladamente publicado na Pacotilha do jornal Correio Mercantil entre junho de 1852 e julho de 1853. Apesar de já existirem duas edições críticas desse livro - a de Terezinha Marinho ${ }^{1}$ e a de Cecília de Lara $^{2}$-, considerou-se, em virtude dos critérios abaixo expostos, necessário recorrer às fontes primárias. Tenha-se claro, contudo, que não se pretendeu fazer uma edição crítica.

Universidade de São Paulo. O autor agradece ao Prof. Reginaldo Pinto de Carvalho pela leitura e pelas oportunas sugestões.

1 Almeida, Manuel Antônio de. Memórias de um Sargento de Milícias. Rio de Janeiro, INL, 1969.

2 Almeida, Manuel Antônio de. Memórias de um Sargento de Milícias. São Paulo, LTc, 1978. 
1) A edição de Terezinha Marinho, empreendimento rigoroso e insuperado, preocupa-se excessivamente com a reconstituição da pronúncia da época. Utilizá-la como base implicaria um trabalho de adaptação e atualização ortográfica tão vasto que se tornou mais prático o retorno às fontes.

1.1) A edição de Terezinha Marinho apresenta, numa comparação superficial, as seguintes divergências relativamente à primeira edição:

1.1.1) t. I, cap. I, p. 107: "ORIGEM, NASCIMENTO E BATISMO." (1ª Edição: "ORIGEM, NASCIMENTO E BATIZADO.”);

1.1.2) t. I, cap. II, p. 112: "Assim chegou aos sete anos." (1 ${ }^{\mathrm{a}}$. Edição: “Assim chegou aos 7 anos.”);

1.1.3) t. I, cap. II, p. 115: "o compadre presenciara” (1ª. Edição: "o Compadre presenciara");

1.1.4) t. I, cap. III, p. 119: “DESPEDIDAS ÀS TRAVESSURAS.” ( $1^{\mathrm{a}}$. Edição: “DESPEDIDA ÀS TRAVESSURAS.”);

1.1.5) t. I, cap. IV, p. 125: "e só então lhe franqueou a entrada." (1ª Edição: “e só então lhe franqueou entrada.”);

1.1.6) t. I, cap. XIV, p. 164: "sensual como um sectário de Mafona." (1ª . Edição: "sensual como um sectário de Mafoma.");

1.1.7) t. I, cap. XIX, p. 191: "silêncio e concentração, de olhos baixos" (1 ${ }^{\text {a }}$. Edição: "silêncio e concentração; de olhos baixos"). O ponto do sinal de ponto e vírgula está borrado, como se alguém tivesse tentado riscá-lo;

1.1.8) t. I, cap. XXI, p. 197: "mas ainda dos conhecidos e amigo dos seus amigos" (1'. Edição: "mas ainda dos conhecidos e amigos dos seus amigos");

1.1.9) t. I, cap. XXI, p. 197: "conhecidos e de suas famílias.[§] Debaixo do mais fútil pretexto" (nem a $1^{\mathrm{a}}$. Edição nem o folhetim abrem parágrafo nesse passo);

1.1.10) t. II, cap. VI, p. 236: "- Porém ia-lhe saindo caro desta vez" (1 ${ }^{\mathrm{a}}$. Edição: “- Porém ia-lhe saindo cara desta vez"; cf., adiante, item 8.16); 
1.1.11) t. II, cap. XVII, p. 277: "Deus os fez e o diabo os ajuntou" (1 . Edição: "Deus os fez e o Diabo os ajuntou”);

1.1.12)t. II, cap. XXII, p. 299: "nem Santo Antônio a tira" (1ª Edição: "nem S. Antônio a tira");

1.1.13) t. II, cap. XXV, p. 314: "fazendo aqui ponto final. [§] F I M" (1ª. Edição: "fazendo aqui ponto final- [§] FIM.”).

2) Já a edição de Cecília de Lara, conquanto seja bem posterior à de Terezinha Marinho, não constitui um passo adiante. Pelo contrário: está tão eivada de erros de revisão, inclusive com "pulos" de trechos inteiros, que sua utilização é impraticável. Mesmo a denominação de "edição crítica" dada a seu trabalho merece reparos: num primeiro cotejo, encontraram-se mais de quatrocentas (!) divergências e supressões em relação às fontes, discrepâncias essas não explicadas nem explicitadas no aparato crítico, o que leva à conclusão de que se trata de erros de revisão. Diga-se desde já que, do ponto de vista da crítica textual, seu trabalho é inferior à maioria das edições didáticas que tomam como base os textos fixados por Terezinha Marinho ou Darcy Damasceno, devendo-se advertir aos editores desavisados que não a utilizem como base em hipótese alguma: estarão oferecendo aos leitores um texto desfigurado. Caberia indagar, numa situação dessas, o que de fato ocorreu quando o livro foi publicado, pois não parece plausível que equívocos de tal monta se devam somente a Cecília de Lara.

2.1) Quanto aos erros de revisão e deslizes na fixação do texto, a relação abaixo limita-se a uma parte dos localizados no corpus (pois não foi possível registrar todos), não englobando, ademais, os do aparato crítico $^{3}$. Para evitar a repetição, consignou-se entre parênteses a lição da primeira edição. Registraram-se os seguintes equívocos indiscutíveis:

\footnotetext{
Os erros, na realidade, estão disseminados por todo o livro, o que torna a maioria de suas informações pouco confiável. A autora, v.g., remete ao trabalho de Marques Rebelo (Vida e Obra de Manuel Antônio de Almeida), sem no entanto lhe apresentar referência bibliográfica alguma. No mesmo caso está o samba-enredo da Portela em 1966, "Memórias de um Sargento de Milícias" (de autoria de Paulinho da Viola), atribuído na edição de Cecília de Lara (p. xI) a Martinho da Vila, que apenas o regravou em 1971 (devo essa observação ao professor e pesquisador de MPB Omar Jubran, a quem agradeço).
} 
JAROUCHE, Mamede Mustafa. A propósito de uma nova edição das Memórias de um Sargento de Milícias.

\section{Tomo I}

1) p. 7, 85: "E esse nascimento" (E este nascimento);

2) p. 7, 86: "o menino de que falamos" (o menino de quem falamos);

3) p. 7, 100: "um colega de Leonardo" (um colega do Leonardo);

4) p. 7, 103: "o minuete na rabeca: e o" (o minuete na rabeca; e o);

5) p. 7, 108: "aferventou como" (aferventou, como);

6) p. 7, 111: "efeito cômico vê-lo em trajes" (efeito cômico vê-lo, em trajes);

7) p. 8, 117: "estava em minha terra" (estava em minha terra,);

8) p. 8, 127: "foi burburinho que" (foi burburinho, que);

9) p. 9, 26: "certo sargento lhe passava" (certo sargento passavalhe);

10) p. 10, 65: "Enfureceu-se de novo:" (Enfurece-se de novo:);

11) p. 10, 72: "embarafustou-se pela" (embarafustou pela);

12) p. 11, 94: "o compadre presenciara" (o Compadre presenciara);

13) p. 11, 95: "colega deste e finalmente" (colega deste, e finalmente);

14) p. 11, 110: "sobre a Maria, das mãos" (sobre a Maria das mãos);

15) p. 11, 111: "afastou-se por ver frustrados" (afastou-se pois a distância conveniente, murmurando despeitado por ver frustrados);

16) p. 12, 128: "vou com isto à justiça..." (vou com isto à justiça!...);

17) p. 12, 129: "-Comadre!..." (-Comadre...);

18) p. 12, 131: "apesar de ele ser um” (apesar de ser ele um);

19) p. 12, 141: "conferência que referíamos" (conferência que referimos); 
20) p. 13, 166: “-Entra, homem...” (-Entre, homem...);

21) p. 13, 186: "mudei de resolução!" (mudei de resolução!...);

22) p. 14, 203: “dizer: Está bom, já agora...” (dizer: - está bom, já agora...);

23) p. 14, 208: "disse o compadre, com um" (disse o compadre com um);

24) p. 16, 40: "o fio de seus raciocínios" (o fio dos seus raciocínios);

25) p. 16, 42: "tem jeito porém" (tem jeito, porém);

26) p. 16, 54: "Está dito há de ser" (Está dito, há de ser);

27) p. 17, 96: "em voz alta; ora” (em voz alta, ora);

28) p. 17, 98: "barbante em cuja” (barbante, em cuja);

29) p. 17, 112: "teve então um pensamento" (teve ele então um pensamento);

30) p. 19, 23: "comprar aventuras" (comprar venturas);

31) p. 19, 30: "não foi a este respeito" (não foi a esse respeito);

32) p. 20, 34: "unidade do gozo," (unidade no gozo,);

33) p. 20, 37: "capitães de navios;" (capitães de navio;);

34) p. 20, 40: "por todos os meios, a posse" (por todos os meios a posse);

35) p. 20, 66: "novas figuras que" (novas figuras, que);

36) p. 21, 5: "um grande aperto de que" (um grande aperto, de que);

37) p. 21, 8: "supremo de tudo o que dizia" (supremo de tudo que dizia);

38) p. 22, 39: "casa da guarda da Sé;" (casa da guarda na Sé;);

39) p. 22, 47: "nigromancia: estava" (nigromancia; estava);

40) p. 23, 74: “ergueram-se e caíram” (ergueram-se, e caíram);

41) p. 23, 77: "disse o major, depois" (disse o major depois);

42) p. 23, 81: “-Então, você em que” (-Então você em que); 
JAROUCHE, Mamede Mustafa. A propósito de uma nova edição das Memórias de um Sargento de Milícias.

43) p. 25, 29: "achar o pequeno; e" (achar o pequeno: e);

44) p. 26, 37: “com eles em negócios," (com eles em negócio,);

45) p. 26, 44: "usavam de rendas e fitas;" (usavam muito de rendas e fitas;);

46) p. 27, 77: "o que é o fado," (o que é fado,);

47) p. 27, 103: "a acabar: termina” (a acabar; termina);

48) p. 28,113 : "hei de ser padre?..." (hei de ser padre?!...);

49) p. 28, 115: "desatou a rir e levou-o" (desatou a rir, e levou-o);

50) p. 29, 8: "gorda, bonanchona ingênua" (gorda, bonanchona, ingênua);

51) p. 29, 26: "era penteado e seguro" (era penteado, e seguro);

52) p. 30, 40: "rótulas para as casas, eram" (rótulas para as casas; eram);

53) p. 30, 47: "que lhe digo; a" (que lhe digo: a);

54) p. 30, 51: “como uma senhora!...” (como de uma senhora!...);

55) p. 31, 76: "casa de Leonardo, e" (casa do Leonardo; e);

$56)$ p. 31, 83: "foi repetindo tudo o que" (foi repetindo o que);

57) p. 31, 87: “o ABC ao menino, porém por" (o A B C ao menino; porém, por);

58) p. 33, 5: "denominavam o Pátio dos Bichos." (denominavam $o$ Pátio dos Bichos.) Faltou itálico no artigo;

59) p. 33, 9: "serviço não sabendo" (serviço não sabemos);

$60)$ p. 33, 13: "cousas do seu tempo e" (cousas do seu tempo, e);

61) p. 33, 29: "cada um dos que ali" (cada um dos que por ali);

62) p. 33, 32: "Faziam-lhe destas" (Faziam-lhes destas);

63) p. 34, 37: "apelido que davam:" (apelido que lhe davam:);

64) p. 34, 44: "porém não lhe serviram" (porém não lhe serviam);

65) p. 34, 51: "gosto de bom gosto," (gosto do bom gosto,);

66) p. 35, 89: "ficou indignado com" (ficou muito indignado com);

67) p. 35, 92: "resultado de tudo isso." (resultado de tudo isto.); 
68) p. 37, 15: "em casa de seu..." (em casa do seu...);

69) p. 38, 42: "No largo do Paço" (No Largo do Paço);

70) p. 38, 43: “a barba; mãos à obra," (a barba: mãos à obra,);

71) p. 38, 45: “Todo barbeiro é” (Todo o barbeiro é);

72) p. 39, 89: "Eram estas as suas únicas" (Eram estas suas únicas);

73) p. 39, 98-9: "histórias: quem é que lhe havia de tomar conta disso?" (histórias; quem é que lhe havia de vir tomar contas disso?);

74) p. 41, 15: "que ele fazia na cabeças de" (que ele fazia na cabeça de);

75) p. 42, 53: “e quem é ela?” (e quem é ela?...);

76) p. 42, 56: “casamento? com quem?” (casamento? com quem?...);

77) p. 42, 63: “-E que mais?” (-E que mais?...);

78) p. 42, 69: "para lá, presente daqui”" (para lá, presentes daqui);

79) p. 43, 79: "irremediável, a mulher tinha” (irremediável. A mulher tinha);

80) p. 43, 84: "Despediu a velha não sem” (Despediu a velha, não sem);

81) p. 43, 96: "soube que se achava" (soube ele que se achava);

82) p. 43, 99: "pudesse por ela satisfazer" (pudesse por ela para satisfazer);

83) p. 43, 104-5: "de umas irregularidades" (de uma irregularidade);

84) p. 44, 117: "disse-lhe ele V. S. já” (disse-lhe ele, V. S. já);

85) p. 47, 5-6: “do F, e já se achava no P," (do $F$ e já se achava no $P$,

86) p. 47, 8: "viu o menino de melhor" (viu menino de melhor); 87) p. 47, 21: "animado em sua obra." (animado na sua obra.);

88 ) p. 47, 22: "O que porém esperava” (O que ele porém esperava); 
JAROUCHE, Mamede Mustafa. A propósito de uma nova edição das Memórias de um Sargento de Milícias.

89) p. 47, 31: "o fim que ele havia de ter" (o fim que ele havia ter); 90) p. 47, 31: "crescesse, o melhor remédio" (crescesse o melhor remédio);

91) p. 48, 43: "amigo do fado tem..." (amigo do fado... tem);

92) p. 48, 56-7: "inferno!!! Ora dá-se? um santo homem.” (inferno!!! ora dá-se? um santo homem...);

93) p. 48, 67: "que nunca lhe fez mal?" (que nunca lhe fez mal?...); 94) p. 49, 73: "bom gênio, que só fora” (bom gênio, e que só fora);

95) p. 49, 99: "o filho para tomar bênção," (o filho para tomar a bênção,);

96) p. 49, 103: "acreditou que se conseguisse" (acreditou que, se conseguisse);

97) p. 51, 7: "pelo afilhado; cada vez" (pelo afilhado: cada vez);

98) p. 51, 16: "ora aceitei o alvo, dei-lhe" (ora acertei o alvo, deilhe);

99) p. 52, 49: "espécie de cantochão" (espécie de cantochão);

100) p. 52, 51: "remédio; Santa férula!" (remédio: santa férula!);

101) p. 52, 55: "É verdade:" (-É verdade:);

102) p. 53, 76: “-Pois você já apanhou?” (-Pois você já apanhou?...);

103) p. 53, 83: "não havia reclamações," (não haviam reclamações,);

104) p. 53, 97: "O pobre homem amuou com" (O pobre homem azoou com);

105) p. 55, 9: "vezes o fora com ele:” (vezes o fora para com ele:); 106) p. 55, 19: "fazia conta: o dinheiro" (fazia conta; o dinheiro). É ponto e vírgula, com vírgula meio apagada, apesar do que afirma Cecilia de Lara no aparato crítico;

107) p. 55, 24: "tomou depois o gosto a" (tomou depois gosto a);

108) p. 55, 27: "as manhãs e tarde em que" (as manhãs e tardes em que); 
109) p. 55, 29: "na Sé, à missa, e mesmo" (na Sé à missa, e mesmo);

110) p. 56, 41: "ao nosso gazeteador" (ao nosso gazeador);

111) p. 56, 56: "os desejos, começou a" (os desejos, e começou a);

112) p. 56, 63: "uma resolução íntima e" (uma resolução última, e);

113) p. 56, 65: "Isso seria muito bom, disse" (-Isso seria muito bom, disse);

114) p. 56, 66-7: “deslumbrou o padrinho; porém” (deslumbrou ao padrinho, porém);

115) p. 56, 69: "Afinal, porém, tantas" (Afinal porém tantas);

116) p. 56, 74: "para fazer a vontade," (para fazer-lhe a vontade,);

117) p. 57, 82: "um sacristão; ajudar" (um sacristão: ajudar);

118) p. 57, 94: "consigo mesma: aquilo" (consigo mesma; aquilo);

119) p. 57, 102: "ao pequeno ficar com" (ao pequeno o ficar com);

120) p. 57, 112: "fossem bater em cheio" (fossem bater de cheio);

121) p. 57, 114: "plastadas de cera" (plastradas de cera);

122) p. 59, 9: "Foi o caso assim." (Foi o caso assim:);

123) p. 59, 32: "à sua voz; enfim aquele" (à sua voz: enfim aquele);

124) p. 60, 44: "bateu e, apesar de todas" (bateu, e, apesar de todas);

125) p. 60, 59: "trocara, em vez de nove" (trocara, e em vez de nove);

126) p. 62, 117-8: "se resolveu abandonar o posto, murmurando, despeitado:" (se resolveu a abandonar o posto, murmurando despeitado:);

127) p. 62, 120: "Acabado o sermão desceu” (Acabado o sermão, desceu); 
JAROUCHE, Mamede Mustafa. A propósito de uma nova edição das Memórias de um Sargento de Milícias.

128) p. 62, 125: "para eles e prendendo" (para eles, e prendendo);

129) p. 62, 129: "nove, sim, senhor: pode" (nove, sim, senhor; pode);

130) p. 62, 150: "não havia de ficar satisfeita" (não havia ficar satisfeita);

131) p. 65, 5: "ou antes, só pensava nela” (ou antes só pensava nela);

132) p. 65, 17: "à janela, abordou-a, e" (à janela abordou[-]a, e);

133) p. 65, 18: "pois logo um padre!?...” (pois logo um padre?!...);

134) p. 65, 31: "nada arranjava e decidiu" (nada arranjava, e decidiu);

135) p. 66, 33: "dê no que der." (dê no que der...);

136) p. 66, 35: "uma função; não nos" (uma função: não nos);

137) p. 66, 37: "o que isso era; viola," (o que isso era: viola,);

138) p. 66, 38: "soube logo que havia," (soube logo do que havia,);

139) p. 66, 40: "Rio de Janeiro: havia" (Rio de Janeiro; havia);

140) p. 66, 50: "vitória e chamaram-no" (vitória, e chamaram-no);

141) p. 66, 52: "já preparado umas poucas," (já pregado umas poucas,);

142) p. 66, 70: "taberneiro" (taverneiro);

143) p. 66, 72: "taverna, sentado" (taverna sentado);

144) p. 67, 75: "estava no chilindró" (estava de chilindró);

145) p. 67, 91: "que queria; tratava-se" (que queria: tratava-se);

146) p. 67, 95: "armada a história era” (armada a história, era);

147) p. 67, 97: "uma desordem, fosse qual" (uma desordem; fosse qual);

148) p. 67, 98: "Assim depois de se regatear" (Assim, depois de se regatear);

149) p. 67, 100: "procurar o Vidigal, deu-lhe" (procurar o Vidigal, e deu-lhe); 
150) p. 68, 117: "alguns faziam reparos nisso," (alguns faziam reparo nisso,);

151) p. 68, 122: “-Isso passa de mais..." (-Isto passa de mais...);

152) p. 68, 124: "há mais de meia hora” (a mais de meia hora);

153) p. 68, 133: "sobre a cabeça: o rapaz" (sobre a cabeça; o rapaz);

154) p. 69, 158: “ouviu-se um pequeno" (ouviu-se então um pequeno");

155) p. 69, 124: "fivela e solidéu” (fivela, e solidéu);

156) p. 69, 166: "com os outros para casa" (com os outros para a casa);

157) p. 71, 13: "porém ele era um simples" (porém também ele era um simples);

158) p. 72, 35: "eram tão cômicas que" (eram tão cômicas, que); 159) p. 72, 54: "repreensões de algum." (repreensões de alguns.);

160) p. 72, 62: "homem você não tem se dado" (homem, você não se tem dado);

161) p. 72, 67: "se aperceber pelas palavras" (se a perceber pelas palavras);

162) p. 72, 78: "e nada lhe arrancava” (e nada lha arrancava);

163) p. 75, 4: "hoje o que nossos leitores" (hoje o que os nossos leitores);

164) p. 75, 6: "casas; penduravam-se” (casas, penduravam-se);

165) p. 75, 9: "o que ainda se pratica," (o que ainda hoje se pratica,);

166) p. 75, 12-3: "em dia de procissão ou concorrer" (em dias de procissão, ou concorrer);

167) p. 75, 25: "aquela até" (aquela, até);

168) p. 76, 38: "vestem as negras na Bahia: é" (vestem as negras na Bahia; é);

169) p. 76, 43: "não usavam de vestidos;" (não usavam de vestido;); 
JAROUCHE, Mamede Mustafa. A propósito de uma nova edição das Memórias de um Sargento de Milícias.

170) p. 76, 49: "nome de trunfas formado" (nome de trunfas, formado);

171) p. 76, 50: "salto alto e" (salto alto, e);

172) p. 76, 58: "lá muito louváveis: nesse” (lá muito louváveis; nesse);

173) p. 76, 68: "branco é muito engomado" (branco e muito engomado);

174) p. 77,81 : "Ihe dava nisso a palma." (lhe levava nisso a palma.);

175) p. 77, 83: "autos de sua demanda" (autos da sua demanda);

$176)$ p. 77, 94: "do pequeno: remontou” (do pequeno; remontou);

177) p. 77, 97: "à festa do batismo, que" (à festa do batizado, que);

178) p. 77, 107: "algumas das suas graçolas," (alguma das suas graçolas,);

179) p 77, 108: "no fim de cada período, e" (no fim de cada período e);

180) p. $78,125:$ "na sua frase de costume:" (na sua frase do costume:);

181) p. 78, 135: "o cavaco, porém bem diz" (o cavaco, porém, bem diz);

182) p. 79, 164: "D. Maria solicitada a dar" (D. Maria, solicitada a dar);

183) p. 79, 165: “-Pois bem, se fosse comigo" (-Pois olhem, se fosse comigo);

184) p. 79, 186: "aos ombros representando" (aos ombros, representando);

185) p. 79, 192: "disse significativamente:" (disse-lhe significativamente:);

186) p. 80, 195: "pois que se tinha inimigos," (pois que, se tinha inimigos,); 
187) p. 81, 15: "possível; nem foi para Coimbra nem" (possível: nem foi para Coimbra, nem);

188) p. 81, 16: "nenhuma dessas cousas," (nenhuma destas cousas,);

189) p. 82, 51: "própria D. Maria que pedira," (própria D. Maria lhe pedira,);

190) p. 82, 54: "depois que lhe perdeu o gosto," (depois que thes perdeu o gosto,);

191) p. 82, 56: "as visitas e que só” (as visitas, e que só);

192) p. 82, 60: “-Ora, afinal venci” (-Ora afinal venci);

193) p. 83, 86: "Então lembras-te dela" (-Então lembras-te dela);

194) p. 85, 19: "apesar que os leitores" (apesar de que os leitores);

195) p. 85, 21: "saía pelas ruas da cidade" (saíam pelas ruas da cidade);

196) p. 85, 25: "palha de abas largas ou" (palha de abas largas, ou);

197) p. 86, 34: "no meio, ordinariamente" (no meio: ordinariamente);

198) p. 86, 37: "e um enorme rutilante" (e um enorme e rutilante);

199) p. 86, 45: "tocava música” (tocava a música);

200) p. 86, 49: "É um grande folião.” (É um grande folião,);

201) p. 86, 63: "lenço de seda encarnada" (lenço de seda encarnado);

202) p. 87, 73: "silêncio e concentração, de" (silêncio e concentração; de);

203) p. 87, 76: "segundo o costume" (segundo o seu costume);

204) p. 87, 83: "ela nunca viu fogo;" (ela nunca viu o fogo;);

205) p. 89, 4: "pouco depois da Ave-Maria," (pouco depois de Ave-Maria,); 
206) p. 89, 14: "D. Maria estava pronta e os esperava com quem" (D. Maria estava já pronta e os esperava com algumas outras pessoas com quem);

207) p. 91, 80: "a sua admiração." (a sua admiração!);

208) p. 91, 81-2: "tão grande, que,” (tão grande que,);

209) p. 93, 5: "ainda que alguns seja” (ainda que para alguns seja);

210) p. 93, 9: "penetrar: fato é que ele" (penetrar: o fato é que ele);

211) p. 93, 30: "A primeira visita depois" (À primeira visita depois);

212) p. 94, 38: "sapatos de fivelas, capote" (sapatos de fivela, capote);

213) p. 94, 41: "Sr. José Manuel assinalava-lhe” (Sr. José Manuel assinava-lhe);

214) p. 94, 48: "ainda dos conhecidos e de suas famílias." (ainda dos conhecidos e amigos dos seus amigos e conhecidos e de suas famílias.);

215) p. 94, 48-9: "famílias. [§] Debaixo do mais fútil” (segue Terezinha Marinho, mas, como já se escreveu acima, nem a $1^{a}$. edição nem o folhetim abrem parágrafo nesse passo);

216) p. 94, 63: "três filha que" (três filhas que);

217) p. 94, 64: "pôr pela porta com um" (pôr pela porta fora com um);

218) p. 94, 65: "feliz: chegou aî" (feliz: achou aí);

219) p. 94, 69: "ele tomando fôlego," (ele tomando novo fôlego,);

220) p. 94, 71: "ambos muito bem." (ambos muito bem...);

221) p. 95, 75: “casa de D. Maria nenhum” (casa de D. Maria, nenhum);

222) p. 95, 77: “especialmente por parte do" (especialmente pela parte do); 
223) p. 95, 79: "afagos com Luisinha, que" (afagos de José Manuel para com D. Maria, e tanto repartia ele esses afagos com Luisinha, que);

224) p. 95, 82: "era muito criança, e" (era muito criança e);

225) p. 97, 5: "menos com isso; vendo que" (menos com isso: vendo que);

226) p. 97, 7: "mandá-lo à Coimbra," (mandá-lo a Coimbra,);

227) p. 97, 17: "ocasião em que isso falou" (ocasião em que nisso falou);

228) p. 97, 29: "gozava de boa fama de ter" (gozava boa fama de ter);

229) p. 98, 32: “de cor tal sujeito:” (de cor o tal sujeito:);

230) p. 98, 43: "a comadre murmurava por" (a comadre murmurava, por);

231) p. 98, 62: "ambas meio a meio:" (ambas de meio a meio);

232) p. 101, 8: "sossego, entregava-se às" (sossego entregava-se às);

233) p. 101, 14: "Entretanto, o que" (Entretanto o que);

234) p. 101, 25: "muito mais entendida na" (muito entendida na);

235) p. 101, 31: "diria isto e aquilo," (diria isto ou aquilo,);

236) p. 102, 51: "para trás e soltou” (para trás, e soltou);

237) p. 102, 58: "imaginar perguntar" (imaginar perguntou);

238) p. 102, 61: "repetiu no mesmo tom." (repetiu no mesmo tom:);

239) p. 102, 77: "porém, não de todo" (porém não de todo);

240) p. 103, 77-8: "percebera o que se" (percebera que o que se);

\section{Tomo II}

1) p. 107, 17: "mil cousas e sem" (mil cousas, e sem);

2) p. 108, 53: "menina... Isso não" (menina... isso não);

3) p. 108, 59: "morrer de susto; nem" (morrer de susto: nem);

4) p. 109, 86: "sujeitas a isso." (sujeitas a isto.); 
5) p. 109, 99: "exclamou a comadre: bem" (exclamou a comadre; bem);

6) p. 109, 103: "isto é um bom agouro," (isto é de bom agouro,); 7) p. 109, 111: "para as de Leonardo-Pataca," (para as do Leonardo-Pataca,);

8) p. 109, 112: "irmão paterno e nosso" (irmão paterno o nosso);

9) p. 111, 11: "de esperanças e” (de esperanças, e);

10) p 111, 17: "atividade: e apesar de" (atividade; e, apesar de);

11) p. 111, 22: "rival do seu afilhado." (rival de seu afilhado);

12) p. 111, 25: "D. Maria de espírito" (D. Maria, de espírito);

13) p. 111, 31: "não continua esta prática" (não continua essa prática);

14) p. 112, 55: "que ainda há dous minutos" (que inda há dous minutos);

15) p. 112, 61: "o hino, corriam" (o hino; corriam);

16) p. 114, 118: "esta, regalando com" (esta, arregalando com);

17) p. 115,4 : "de um raio; a velha" (de um raio: a velha);

18) p. 115, 20: "nos seus arranjos..." (nos seus arranjos.);

19) p. 115, 22: "ouviu bater a porta," (ouviu bater à porta,);

20) p. 116, 42: "a cabeça, disse:" (a cabeça, disse por entre dentes:);

21) p. 116, 59: "época da vida: a cabeça” (época da vida; a cabeça);

22) p. 116, 69: "o sol iluminava de dia," (o sol o iluminava de dia,);

23) p. 117, 110: "jurou e trejurou" (jurou e tresjurou);

24) p. 120, 65: "mérito; corria a seu" (mérito: corria a seu);

25) p. 120, 71: "informações; e" (informações, e);

26) p. 124, 20: "avermelharam-se-lhe os" (avermelharam-se-lhe imediatamente os); 
27) p. 124, 64: "a noite, acenderam-se" (a noite; acenderam-se); 28) p. 124, 67: "homem não havia de morrer" (homem não havia morrer);

29) p. 125, 85: "ficaram com isto muito" (ficaram com isso muito);

30) p. 125, 89: "disse enternecida." (disse enternecida:);

31) p. 126, 134: "com seu filho" (com o seu filho);

32) p. 127, 5: "forçoso no final de" (forçoso no fim de);

33) p. 127, 26: "sem dar Deus te salve -" (sem dar - Deus te salve -);

34) p. 127, 32: "achava junto dele; com" (achava junto dele: com);

35) p. 128, 33: "fios, uma porção" (fios, e uma porção);

36) p. 129, 102: "ia-lhe saindo caro" (ia-lhe saindo cara);

37) p. 129, 111: "para isto: tomar as dores" (para isto: tomam as dores);

38) p. 130, 117: "um Oficial de Justiça...” (um Oficial de Justiça.);

39) p. 130, 129: "Ao sair escoravam-se" (Ao sair escoravam-na);

40) p. 130, 133: “-Deixem-me, deixem-me," (-Deixe-me, deixeme,);

41) p. 131, 10: "caminho que havia de tomar." (caminho que havia tomar.);

42) p. 131, 16: "umas poucas gargalhadas" (umas poucas de gargalhadas);

43) p. 131, 17: "pareceu-lhe que tinham" (pareceu-lhe que lhe tinham);

44) p. 131, 25: "resto de jantar," (restos de um jantar,);

45) p. 131, 31: "porque o movimento que" (porque com o movimento que);

46) p. 132, 39: "Quis fazer cerimônias, mas" (Quis fazer cerimônia, mas);

47) p. 132, 40: "das moças serviu-o e" (das moças serviu-o, e); 
JAROUCHE, Mamede Mustafa. A propósito de uma nova edição das Memórias de um Sargento de Milícias.

48) p. 132, 60: "para casa de meu pai..." (para a casa de meu pai...);

49) p. 133, 81: "inda não. Vidinha” (inda não: Vidinha);

50) p. 133, 82: "meus suspiros" (os meus suspiros);

51) p. 133, 89: "largos, peitos alteados," (largos, peito alteado,);

52) p. 133, 97: "uma toda insípida" (uma toada insípida);

53) p. 133, 104: "Os meus queixumes.” (Os meus queixumes,);

54) p. 133, 105: "Nem de ciúmes" (Nem de ciúme);

55) p. 133, 107: "São de saudades" (São das saudades);

56) p. 135, 3: "depois de um longo" (depois de longo);

57) p. 135, 5: "casa da Rua da Vala." (casa da rua da Vala.);

58) p. 135, 16: "da qual se achava" (da qual se acha);

59) p. 136, 55: "acentuado: respondeu" (acentuado; respondeu);

60) p. 137, 93: “À vista disso” (À vista disto);

61) p. 139, 4-5: "estava ele tranquiilamente e" (estava ele tranquiilo e);

62) p. 139, 17: "as raparigas parecem que gostam" (as raparigas parece que gostam);

63) p. 139, 28: "falo e falo muito;" (falo, e falo muito;);

64) p. 139, 29: "não é trabalho que cansa." (não é trabalho que canse.);

65) p. 140, 59: "Isto é cousa que se creia?!" (Isto é cousa que se creia?!...);

66) p. 140, 66: "temos contas a ajustar..." (temos contas que ajustar...);

67) p. 141, 77: "bem sabia qual era." (bem sabia ela qual era.);

68) p. 141, 112: "o cal entornado" (o caldo entornado);

69) p. 142, 124: "respeito do José Manuel;" (respeito de José Manuel;);

70) p. 142, 137: “como já se falava” (como lá se falava); 
71) p. 142, 142: "começou a aplacar" (começou-lhe a aplacar);

72) p. 143, 166: "mesma tinha a pouco" (mesma tinha há pouco);

73) p. 143, 170: "D. Maria mesmo lhe" (D. Maria mesma lhe);

74) p. 143, 171: “disse, referindo-se:” (disse, referindo-se a Luisinha:);

75) p. 145, 7: "do que ter cada um," (do que ter cada casa um,);

76) p. 145, 19: "os pais por cima” (os pais em cima);

77) p. 145, 24: "estava ou viria a estar" (estava ou viria estar);

78) p. 146, 34: "a intenção e o desejo" (a intenção e desejo);

79) p. 146, 36: "tinha de lutar com" (tinha ele de lutar com);

$80)$ p. 146, 45: "tornou mais" (tornou muito mais);

81) p. 146, 46: "quer porque fosse" (quer porque agora fosse);

82) p. 146, 48: "bofes pela boca, pelo" (bofes pela boca pelo);

83) p. 146, 64: "amorosa, abraço" (amorosa, um abraço);

84) p. 147, 96: "alguma cousa ainda" (algum ousa ainda);

85) p. 147, 112: "apesar disso e dos" (apesar disso e apesar dos);

86) p. 148, 125: "dirigiu-se, entraram" (dirigiu-se, e entraram);

87) p. 149,4 : "do que acabava de" (do que se acabava de);

$88)$ p. 149,6 : "afilhado para a casa" (afilhado para casa);

89) p. 149, 20: "acompanhada de grande" (acompanhada da grande);

90) p. 149, 24: "velhas conversaram, os" (velhas conversavam, os);

91) p. 149, 32: "tens nesta cabeça” (tens nessa cabeça);

92) p. 150, 71: "conhecimento de Leonardo" (conhecimento do Leonardo);

93) p. 151, 76: "Quem estivesse distraído" (Quem estivesse menos distraído);

94) p. 151, 78: "cochichavam-se como" (cochichavam como);

95) p. 151, 86: "Vidigal deixar passar" (Vidigal deixou passar); 
JAROUCHE, Mamede Mustafa. A propósito de uma nova edição das Memórias de um Sargento de Milícias.

96) p. 151, 88: "medo de mim que" (medo de mim, que);

97) p. 151, 94: "não sabia!... pois," (não sabia!... Pois,);

98) p. 157, 21: "pensamentos íntimos -" (pensamentos íntimos: - );

99) p. 158, 39: "a que se assemelhava," (a que assemelhava,);

100) p. 158, 67: “-Qual! aí está ele.” (-Qual! aí está ele!);

101) p. 158, 69: "irmãos rivais que ficaram" (irmãos rivais, que ficaram);

102) p. 159, 97: "arranjasse a soltura" (arranjasse depois a soltura);

103) p. 159, 104: “tão regular e tão lícita.” (tão regular e tão lícita.);

104) p. 161, 26: "foi-se embora" (foi-se embora,);

105) p. 162, 36: "então que fora” (então qual fora);

106) p. 162, 46: "dous rivais; tinham" (dous rivais: tinham);

107) p. 162, 53: "que lhe levaram; era" (que lhe levaram: era);

108) p. 166, 58: "sincero este sentimento" (sincero esse sentimento);

109) p. 169, 22: "além; isto sem cessar" (além; isso sem cessar);

110) p. 169, 28: “decompõem os vizinhos; esta” (descompõem os vizinhos: esta);

111) p. 171, 80: "redobrou os passos:" (redobrou a passos:);

112) p. 171, 90: "que lhe era inútil" (que lhe seria inútil);

113) p. 173, 18: "toma-largura, que achando-se" (toma-largura que, achando-se);

114) p. 173, 28: "Vidinha, descomposta pela" (Vidinha, decomposta pela);

115) p. 174, 42: "além disso ao" (além disso, ao);

116) p. 174, 50: "Deus os fez e o diabo" (Deus os fez e o Diabo);

117) p. 174, 71: “do amor de Vidinha," (do amor da Vidinha,);

118) p. 175, 75: "alcançou-a; acompanhou-a" (alcançou-a: acompanhou-a); 
119) p. 177, 14: "rapariga, fostes fazer" (rapariga, foste fazer);

120) p. 177, 16: "agora venha ele cá," (agora venha ele para cá,);

121) p. 178, 51: “em diversos pontos," (em diversos outros pontos,);

122) p. 178, 70: “aquela gente, que tão" (aquela que tão);

123) p. 178, 71: "Nas invectivas a" (Nas inventivas a);

124) p. 179, 73: "contra as razões" (contra ele as razões);

125) p. 180, 122-3: "tinha alguns motivos" (tinha algum motivo);

126) p. 180, 124: "na ocasião do jantar," (na ocasião de jantar,);

127) p. 180, 131: "menos esperavam," (menos o esperavam,);

128) p. 180, 133: "de sua esquerda e da sua" (de sua esquerda e de sua);

129) p. 181, 9: "desdita e desdita de" (desdita, e desdita de);

130) p. 182, 56: "Papai lêlê, seculorum." (Papai lêlê, seculorum.);

131) p. 183, 90: "e a toda das cantigas." (e a toada das cantigas. $)^{4}$;

132) p. 183, 96: "no chão e a chusma" (no chão, e a chusma);

133) p. 184, 118: "seguraram-no e o major" (seguraram-no, e o major);

134) p. 186, 36: "certas habilidades e" (certas habilidades, e);

135) p. 186, 41: "finalmente, eis aqui" (finalmente, - eis aqui);

136) p. 186, 46: "era esse o seu” (era este o seu);

137) p. 186, 50: "descobriu; em dias" (descobriu: em dias);

138) p. 186, 52: "Teotônio era banqueiro" (Teotônio era o banqueiro);

139) p. 186, 64: "e segundo a moda, foi” (e, segundo a moda, foi);

140) p. 187, 76: "Leonardo-Pataca e” (Leonardo-Pataca, e);

141) p. 187, 100: "ficado à pouca" (ficado a pouca);

142) p. 187, 104: "despertasse suspeita:” (despertasse suspeitas:);

4 Devo esta correção ao Prof. Reginaldo Pinto de Carvalho. 
JAROUCHE, Mamede Mustafa. A propósito de uma nova edição das Memórias de um Sargento de Milícias.

143) p. 188, 119: "noite do papai lê-le," (noite do papai-lêlê,);

144) p. 188, 134: "logro! É o Leonardo;" (logro! é o Leonardo;);

145) p. 188, 136: "Aquele brejeiro," (-Aquele brejeiro,);

146) p. 188, 142: "todos tremenda" (todos uma tremenda);

147) p. 189, 157: "homem, seja como" (homem, seja lá como);

148) p. 191, 20: "limpa; ele há de" (limpa; ele há de);

149) p. 192, 52: "voltava a seu marido" (votava a seu marido);

150) p. 192, 62: "precedera o casamento" (precedera ao casamento);

151) p. 192, 64: "laço de amizade" (laço da amizade);

152) p. 193, 73: "e mal fadada.” (e mal fadada!);

153) p. 193, 88: "missa, só não voltaram" (missa, não só voltaram);

154) p. 193, 94: "logo em alvoroço," (logo em alvoroto,);

155) p. 195, 13: "ergueu-se de sua banquinha," (ergueu-se da sua banquinha,);

156) p. 195, 18: "uma boa ação!" (uma boa ação!...);

157) p. 195, 23: "em que deu, é sina,” (em que deu; é sina,);

158) p. 195, 24: "dia; não comadre: isso" (dia; não, comadre; isso);

159) p. 196, 20: "aflição." (aflição...);

160) p. 196, 33: "vinha tornou-se a" (vinha tornou-me a);

161) p. 196, 37: "de que se diz" (de quem se diz);

162) p. 196, 42: "gosto; daí é que” (gosto: daí é que);

163) p. 196, 44: "tempo destas histórias" (tempo desta história);

164) p. 196, 48: "primeiro: temos estudado" (primeiro; temos estudado);

165) p. 196, 52: "que não concordaram" (que não concordarem);

166) p. 196, 63: "senhora, vamos, que" (senhora, vamos; que);

167) p. 197, 84: "o que puder: vou” (o que puder; vou);

168) p. 197, 93: "nem Santo Antônio" (nem S. Antônio); 
169) p. 197, 98: "para casa do major." (para a casa do major.);

170) p. 199, 7: "a farda: como" (a farda; como);

171) p. 199, 22: "ainda por cima ficava" (ainda em cima ficava);

172) p. 200, 35: "onde fosse: mas" (onde fosse; mas);

173) p. 200, 51: "achou a ocasião bem” (achou ocasião bem);

174) p. 200, 68: "não vem nada ao caso.” (não vem nada ao caso...);

175) p. 201, 87: "as três a um só" (as três, a um só);

176) p. 201, 91: "Foi uma” (Foi então uma);

177) p. 202, 118: "O major desanuviou" (O major, desanuviou);

178) p. 202, 128: "foi rei sempre tem" (foi rei sempre teve);

179) p. 203, 27: "E não era, nós já” (E não eram, nós já);

180) p. 203, 29: "conveniências, para” (conveniências, e para);

181) p. 204, 37: "galões do caixão, até" (galões do caixão até);

182) p. 204, 51: “Leonardo: e não" (Leonardo; e não);

183) p. 204, 56: “os dous não se viam;” (os dous se não viam;);

184) p. 204, 71: "fato em fato chegou" (fato em fato, chegou);

185) p. 207, 3: "tempo de nojo, e" (tempo do nojo, e);

186) p. 207, 19: "todo derranjado, graças" (todo desarranjado, graças);

187) p. 207, 26: "Ora soldado, naquele" (Ora, soldado, naquele); 188) p. 207, 29: "meditações, abandonava-se, e" (meditações, abandonava-as, e);

189) p. 208, 35: "cousa de andar de pressa” (cousa de andar depressa);

190) p. 208, 41: "Infelizmente ocorria-Ihe" (Infelizmente ocorrialhes);

191) p. 208, 44: "ilegítima os repugnava." (ilegítima lhes repugnava.);

192) p. 208, 56: "intervalos do Padre-Nosso" (intervalos de Padre-Nosso); 
193) p. 208, 60: "vez, e não foi feliz;” (vez, e não fui feliz;);

194) p. 209, 88: "não se disfarçar e obter perdão" (não só disfarçar e obter o perdão);

195) p. 209, 90: “em casa de Maria-Regalada” (em casa da MariaRegalada);

196) p. 209, 106-107: "aqui ponto final. [§] FIM" (aqui ponto final- [§] FIM.).

3) O texto da Ateliê baseou-se, como ficou dito, no da primeira edição (1854-1855) cotejado com o da Pacotilha do jornal Correio Mercantil (1852-1853). Divergiu-se do estema proposto por Terezinha Marinho e por Cecília de Lara em suas edições críticas: ambas sugerem que um manuscrito (perdido) foi a origem do texto no jornal, e que o texto no jornal, por sua vez, originou a primeira edição. A divergência, para a fixação do texto, fundamentou-se no fato de que as colunas do jornal não poderiam ter servido de base para a primeira edição em livro porque, primeiro, a impressão é precária e, segundo, as entrelinhas não permitem emendas. Infelizmente, as condições de trabalho nas gráficas brasileiras são, em grande parte, ignoradas. Em condições normais, os originais remetidos pelos redatores à oficina seriam destruídos após a composição, muito embora não se possa afirmar categoricamente que isso sempre ocorresse; não seria nada absurdo imaginar que qualquer redator, desde que acreditasse merecer seu texto mais do que a simples publicação em jornal, acorresse às oficinas no intuito de resgatar os originais. Por isso, torna-se plausível a hipótese de que o manuscrito (perdido, repita-se, até prova em contrário) tenha servido de base tanto para a publicação no jornal como para a edição em livro - e assim, respeitados os trechos em que ocorreu emenda, estar-se-ia diante de duas leituras do mesmo manuscrito, o que permitiu, em muitos momentos, valorizar o texto dado à estampa no jornal. Outra possibilidade é que o autor, tendo perdido o original manuscrito, recopiasse o texto para publicação em livro, especialmente quando as modificações fossem muitas. Confira-se mais abaixo, todavia, a ocorrência de alguns lapsos que sugerem ter sido a correção feita sobre um 
original primitivo, e não de nova cópia especialmente feita para a edição em livro - especialmente nas flagrantes distorções provocadas, nas flexões verbais, pelas constantes trocas entre "v" e " $r$ ".

Eis a lista dos procedimentos adotados, e sua explicação:

3.1) A ortografia foi inteiramente atualizada sem que se visse necessidade de justificativas. Mesmo em casos como, v.g., proromper, resoar ou presentira, (que são as formas registradas em dicionários da época ${ }^{5}$ ), não se viu necessidade de explicação, bem como no caso de "cousa", "doudo", "dous" etc. Num ou noutro caso, devidamente explicitada, apresenta-se alguma variação.

3.2) Mantiveram-se todos os casos de flexão de número do verbo haver, no sentido de existir, hoje considerada incorreta. A variação do uso - ora flexionando o verbo ("haviam testemunhas"), ora não ("havia homens") - não discrepa do de outros autores do período, conforme registrou Terezinha Marinho.

3.3) Também se mantiveram os casos em que não ocorre a preposição "de" entre o verbo auxiliar haver e o verbo principal: trata-se de arcaísmo adrede utilizado ${ }^{6}$. Abaixo, a lista de todas as ocorrências, com o n. ${ }^{\circ}$ de página da primeira edição:

3.3.1) "pelo que aquilo the havia custar" (t. I, cap. II, p. 11);

3.3.2) "o fim que ele havia ter," (t. I, cap. XI, p. 68);

3.3.3) “como não havia ficar” (t. I, cap. XIV, p. 91);

5 Cf. Morais e Silva, Antônio. Dicionário da Língua Portuguesa. Lisboa, Tipografia Lacerdina, 1813, 2 v., e Vieira, Domingos. Grande Dicionário Português ou Tesouro da Língua Portuguesa. Porto, Chardron, 1871-1872, 5 v. (na realidade, esse último está apenas baseado em manuscritos do frei Domingos Vieira, da "ordem dos eremitas calçados de Santo Agostinho").

6 Cf. Dias, Augusto Epifânio da Silva. Sintaxe Histórica Portuguesa. Lisboa, Clássica, 1954, p. 259; Almeida, Napoleão Mendes de. Dicionário de Questões Vernáculas. São Paulo, Ática, 1996, p. 241, e Ali, M. Said. Gramática Histórica da Língua Portuguesa. Rio, Acadêmica, 1971, p. 340. A respeito de regência correlata, leia-se a curta observação de Sousa da Silveira: "Um fato interessante do português arcaico é o subentender-se o verbo auxiliar do futuro ou condicional: 'viver hei se de mim pensar, ou morrer, se mim non amar', isto é, 'viver hei (=viverei), se em mim pensar, ou morrer hei (=morrerei), se me não amar". (Lições de Português. Rio de Janeiro, Livros de Portugal, 1964, p. 103). 
JAROUCHE, Mamede Mustafa. A propósito de uma nova edição das Memórias de um Sargento de Milícias.

3.3.4) "Se eu fosse parente da rapariga havia pôr uma demanda" (t. II, cap. III, p. 18);

3.3.5) "este homem não havia morrer sem ter feito seu testamento" (t. II, cap. V, p. 32);

3.3.6) "que te havia desancar" (t. II, cap. VI, p. 41);

3.3.7) "que havia tomar" (t. II, cap. VII, p. 43);

3.3.8) "não o havia esquartejar" (t. II, cap. IX, p. 57);

3.3.9) "tão certos que eles se haviam recusar" (t. II, cap. XVIII, p. 108);

3.3.10) "ainda havemos chegar a tempo" (t. II, cap. XXII, p. 141);

3.3.11) "que haviam dizer de mim" (t. II, cap. XXIII, p. 147);

3.4) Ao lado dessas, há outras em que o uso está "normalizado". Por exemplo: "hei de te curar..." (t. I, cap. XIII, p. 83); "Hei de ficar ainda mais contente" (t. II, cap. XXIII, p. 148). Somente um estudo estilístico minucioso poderá mostrar os motivos dessa variação, e até mesmo o que porventura tenha sido correção indevida perpetrada por tipógrafos e revisores.

4) Pontos finais, vírgulas e pontos-e-vírgulas foram colocados para fora das aspas ou dos travessões nos seguintes passos (a referência entre parênteses é da primeira edição):

4.1) o terrível -Dou-me por citado.- (t. I, cap. I, p. 6);

4.2) «Farte-se de travessuras por este resto da semana,» e (t. I, cap. III, p. 24);

4.3) «farte-se de travessuras;» espiou (t. I, cap. III, p. 25);

4.4) «está aí o Vidigal,» mudavam-se (t. I, cap. V, p. 32);

4.5) diz sempre «venha a nós o pão nosso.» Ir (t. I, cap. XI, pp. 6768);

4.6) a quem chamavam -Juca,- juntaram (t. I, cap. XV, p. 95);

4.7) rancho chamado das -Baianas,- que (t. I, cap. XVII, p. 106);

4.8) intitulava -O naufrágio dos potes.- (t. I, cap. XXII, p. 137);

4.9) «Se os meus suspiros pudessem.» (t. II, cap. VII, p. 46); 
4.10) «Quando as glórias que eu gozei.» (t. II, cap. VII, p. 46);

4.11) «Se os meus suspiros pudessem.» (t. II, cap. VII, p. 47);

4.12) -Deus lhe fale n'alma,- (t. II, cap. IX, p. 57);

4.13)«abriu-me os olhos sobre outros pontos;» (t. II, cap. IX, p. 61);

4.14) pelo tal -primeiro amor:- (t. II, cap. X, p. 65);

4.15) - conta a sua vida e de toda a família desde as eras primitivas.- (t. II, cap. XI, p. 69);

4.16) -Cuidado! eu aqui estou.- (t. II, cap. XIII, p. 82);

4.17) -É agora; quebro por ali fora, e bato pernas.- (t. II, cap. XIII, p. 82);

4.18) -Embarafusto por ali dentro, e sumo-me.- (t. II, cap. XIII, p. 82);

4.19) como quem dizia -entendo,- (t. II, cap. XVII, p. 104);

4.20) e então ele não diz -ora?- (t. II, cap. XVII, p. 105);

4.21) os -Cajueiros,- onde a família (t. II, cap. XVIII, p. 112);

4.22) rigoroso -Papai lêlê,- (t. II, cap. XIX, p. 118);

4.23) e finalmente, -eis aqui o seu mais raro talento,- (t. II, cap. XX, p. 123; aqui também se eliminou a vírgula após "finalmente"; a lição de J [e finalmente, e eis aqui o seu mais raro talento,] evidencia que, ao se acrescentarem os travessões, esqueceu ao autor cortar as vírgulas).

4.2) Obs.: a colocação desses sinais dentro dos travessões ou das aspas é procedimento sistemático no texto, tanto no jornal como na primeira edição em livro. Pode-se, assim, considerar erro de revisão ou descuido - que foi mantido, por corresponder às normas adotadas para a atualização - a ocorrência verificada na página 5 , cap. I, t. I: "chamava-se nesse tempo -O canto dos meirinhos-; e bem", ou a ocorrência da página 95, cap. XV, t. I: "chamaram-no a princípio -Chico-; porém".

5) Foram corrigidos os evidentes erros de revisão abaixo ( "J" indica a lição do texto do jornal): 
5.1) t. I, cap. II, p. 17: "pôs-se a passear pela loja com as mão cruzadas para trás” [J: mãos];

5.2) t. I, cap. V, p. 34: "Sr. major, respondeu ele acabrunhado," [J: -Sr. major,]. Trata-se de fala de personagem;

5.3) t. I, cap. VI, p. 38: "e depois de ter formado mil planos, disse consigo.” [J: consigo:]. Procedimento sistemático adotado no texto;

5.4) t. I, cap. V, p. 39: “que morava no largo do Bocio,” [J: Rocio,]. Embora esteja apagada a primeira letra, é possível ver que se trata de "B" e não de "R";

5.5) t. I, cap. V, p. 39: "Encontrando-se nessa noite, como já sabem os leitores, como o nosso futuro clérigo," [J: com o nosso];

5.6) t. I, cap. VII, p. 46: "Apertara-lhe as saudades" [J: Apertaramlhe]. Erro de revisão óbvio: as modificações do jornal para o livro, no caso das Memórias, jamais se efetuam com o objetivo de produzir erros gramaticais, seja na fala do narrador, seja na dos personagens;

5.7) t. I, cap. VIII, p. 50: "suas feições quebradras pela idade" [J: quebradas];

5.8) t. I, cap. IX, p. 55: “saber fazer render o nova posição.” [J: a nova];

5.9) t. I, cap. X, p. 63: “apenas sentisse qua a Maria sofria” [J: que a];

5.10) t. I, cap. XII, p. 77: "dirigiu-lhe quanto injúria sabia de cor." UJ: quanta injúria];

5.11) t. I, cap. XIII, p. 81: "e faziam juntos o serviço e as maroteiros" [J: maroteiras];

5.12) t. I, cap. XIII, p. 81: “a igreja, para o qual, dizia ele,” [J: para a qual,];

5.13) t. I, cap. XIII, p. 82: "soltou uma exclamação desurpresa” [J: de surpresa];

5.14) t. I, cap. XIV, p. 90: por causa daquelo endiabrado?! [J: daquele];

5.15) t. I, cap. XV, p. 93: "as caçoados" [J: as caçoadas]; 
5.16) t. I, cap. XVI, p. 102: "pudesse ter sido obra sua," JJ: obra sua.];

5.17) t. I, cap. XVII, p. 110: “queria pouca mais ou meno dizer:” [J: pouco mais];

5.18) t. I, cap. XVII, p. 111: “Dirigindo-se depois ao pequeno.” [J: pequeno:]. Cf. 5.3, supra;

5.19) t. I, cap. XIX, p. 120: "isto enfeitado com grinadas de flores," [J: grinaldas];

5.20) t II, cap. I, p. 8: “-Ó comadre, dê cá lá” [J: -Ó compadre,]. A fala é da comadre;

5.21) t. II, cap. II, p. 15: “-A comadre interrompeu," [J: A comadre]. Não é fala de personagem;

5.22) t. II, cap. III, p. 19: "os olhos, até aqui amortecido, começavam" [J: amortecidos];

5.23) t. II, cap. IV, p. 24: "Entre essas umas havia de que ainda” [J: uma havia];

5.24) t. II, cap. V, p. 33: "Depois diss tratou-se de resolver" [J: disso];

5.25) t. II, cap. VI, p. 38: “concertou a gargante, dizendo” [J: garganta,];

5.26) t. II, cap. VII, p. 4: "trocados os comprimentes" [J: trocados os comprimentos];

5.27) t. II, cap. VII, p. 46: “confiança cega no dia de amanhãa,” IJ: amanhã,];

5.28) t. II, cap. IX, p. 57: "antes de de lhe dar tempo de" (antes de lhe dar [J: antes de dar-lhe]);

5.29) t. II, cap. IX, p. 61: “chegaram à conclusão” [J: chegara]. 0 sujeito é o mestre de reza;

5.30) t. II, cap. IX, p. 61: “o Leonardo embarasfustou pelo" [J: embarafustou];

5.31) t. II, cap. XIV, p. 90: "Valham-me trezentos diabos!..." [J: Valham-me]. Cf. 5.2, supra; 
5.32) t. II, cap. XVIII, p. 109: "esperanças de ver checar o Leonardo" [J: chegar];

5.33) t. II, cap. XXV, p. 158: “cumpriria o gosto do majar.” [J: major].

6) Foi mantida a redação constante do texto do jornal (ou a lição ali sugerida) sempre que pareceu mais clara, correta ou adequada (conforme, claro está, os critérios do organizador), independentemente de outras considerações, ainda que muitas delas sejam plenamente justificáveis. Eis a lista:

6.1) t. I, cap. II, pp. 13-14: "Enfurece-se de novo: suspendeu o menino pelas orelhas, fê-lo dar no ar uma meia volta, ergue o pé direito, assenta-lhe em cheio sobre o glúteos" J: "Enfurece-se de novo: suspende o menino pelas orelhas, fá-lo dar no ar uma meia volta, ergue o pé direito, assenta-lhe em cheio sobre os glúteos" [mantido pela maior coerência dos tempos verbais; o trecho já havia causado estranheza aos organizadores da edição de 1863, que botaram todos os verbos no passado];

6.2) t. I, cap. II, p. 17: “-O passado passado; vamos...” J: "passado, passado;" [no texto, as elipses se marcam por vírgula, como nas duas ocorrências registradas no t. II, p. 148: "agora, o passado, passado;" e "o dito, dito..."];

6.3) t. I, cap. II, p. 18: “o passado passado.” J: “o passado, passado." [cf. item anterior];

6.4) t. I, cap. II, p. 19: “adeus compadre!" J: "adeus, compadre!”; 6.5) t. I, cap. III, p. 22 "Assim a primeira afeição" J: "à primeira afeição";

6.6) t. I, cap. V, p. 35: "falar-lhe, isto quer dizer" J: "falar-lhe. Isto quer";

6.7) t. I, cap. VI, p. 37: “-Então vizinho, nada?” J: “-Então, vizinho, nada?" [o vocativo, no texto, habitualmente é posto entre vírgulas];

6.8) t. I, cap. VI, p. 39: "havia festa de ciganos, (e este costume ainda hoje se conserva);" J: "havia festa de ciganos (e este costume ainda hoje se conserva);"; 
6.9) t. I, cap. VI, p. 40: "foram colocar-se juntos do oratório.” J: "junto do" [embora possa justificar-se como caso de contaminação ${ }^{7}$, foi considerado erro de revisão];

6.9a) t. I, cap. VI, p. 40: “Ora, uma só pessoa,” J: "Ora uma só pessoa,";

6.10) t. I, p. 41: "vagarosamente, outras vezes" J: "vagarosamente; outras vezes";

6.11) t. I, cap. VIII, p. 49: "existe no saguão do paço imperial, que no tempo em que se passou esta nossa história se chamava palácio del-rei uma saleta” J: "del-rei, uma” [normalmente, o texto põe as explicativas entre vírgulas];

6.12) t. I, cap. VIII, p. 49: "que o rei tinha a seu serviço não sabemos" J: "serviço, não";

6.13) t. I, cap. VIII, p. 50: "que bem denotava que seu tempo de rapaz não fora a respeito de beleza mal favorecido;" J: "que no seu tempo" [é o homem, e não o tempo, que não fora mal favorecido]; 6.14) t. I, cap. IX, p. 53: "nem lhe veio a curiosidade indagá-lo" J: "a curiosidade de o indagar" [por isso, nesta edição optou-se, em vez de "à curiosidade", por "a curiosidade de indagá-lo"];

6.15) t. I, cap. XI, p. 68: "os suplícios, isto faz” J: "os suplícios. Isto faz";

6.16) t. I, cap. XI, p. 80: "saíam as verdadeiras beatas," J: "saíam as derradeiras beatas,";

6.17) t. I, cap. XIII, p. 82: "mais amor aquela vida" J: "àquela”;

6.17a) t. I, cap. XIII, p. 82: "aperfeiçoou-se em pouco tempo.” J: "aperfeiçoou-as em pouco tempo.”;

6.18) t. I, cap. XIV, p. 86: "aquele sermão anual era o meio por que ele esperara chegar a todos os fins, a que contava dever toda a sua elevação futura;" J: "por que ele esperava chegar" [o imperfeito é mais condizente com o contexto do que o mais que perfeito;

Cf. Silveira, Sousa da. Lições de Português, op. cit., p. 142. 
ademais - basta consultar os manuscritos da época-o " $v$ " facilmente se confundiria com o " $r$ "];

6.19) t. I, cap. XIV, p. 87: “costumava a estar;” J: "costumava estar;";

6.20) t. I, cap. XV, p. 93: "enquanto se lembrou da cadeia, dos granadeiros e do Vidigal esqueceu-se da cigana," J: "e do Vidigal, esqueceu-se" [a pontuação confere maior clareza];

6.21) t. I, cap. XV, p. 94: “eu como estou estou muito bem;” J: "estou, estou";

6.22) t. I, cap. XV, p. 96: "pensei que ainda estava de xilindró” J: "estavas" [por coerência, uma vez que, nessa passagem, ambos os personagens usam corretamente a segunda pessoa do singular: "te venho procurar.", "vai-te embora... tu não és capaz", "sempre foste", "mas tu... tu que és mestre”, "onde queres tu”, "-Não te hás de”];

6.23) t. I, cap. XV, p. 98: "O Chico Juca foi acometido por um pouco; porém ligeiro e destimido, distribuía” J: “destemido,” [cf., adiante, 6.53];

6.24) t. I, cap. XV, p. 99: "se era sujeito já conhecido, e que não era aquela a primeira em que entrava ficava de lado, e um granadeiro" [colocou-se uma vírgula entre "entrava" e "ficava" por sugestão de J: "a primeira em que entrava, era posto de". A substituição de "era posto" por "ficava" pode ter levado o tipógrafo a pular a vírgula, que nesse caso é necessária e não discrepa do uso que se verifica no restante do texto];

6.25) t. I, cap. XVI, p. 102: "esta ficou-se com isso, e foi essa a fortuna do Leonardo." J: "picou-se com isso," [e esse erro pode ser uma evidência de que o texto foi composto sobre original manuscrito]; 6.25a) t. I, cap. XVI, p. 104: "obstinação deixara” J: "obstinação, deixara";

6.26) t. I, cap. XVII, p. 106: "outro tanto: a que" J: "outro tanto; a que";

6.27) t. I, cap. XVII, p. 111: "O menino chegou-se com um ar entre vexado e capadoçal, colocou-se em pé entre a madrinha e 
a vizinha." J: "capadoçal, e colocou-se" [é a ocorrência habitual no texto];

6.28) t. I, cap. XVII, p. 111: "- Valha-te, Deus, menino! disse a comadre." J: "-Valha-te Deus,";

6.29) t. I, cap. XVII, p. 112: "disse a final D. Maria” J: "afinal";

6.30) t. I, cap. XVII, p. 113: “Isaac: logo atrás” J: "Isaac; logo atrás";

6.31) t. I, cap. XVII, p. 113: "retiravam-se os convidados” J: "retiraram-se";

6.32) t. I, cap. XXI, p. 131: "que por sinal lhe deu bem má vida. [§] E também ela” [Nesse passo, seguiu-se a lição de J, que não abre parágrafo. No texto, as falas das personagens estão habitualmente em parágrafos contínuos];

6.33) t. I, cap. XXII, p. 136: "No meio de tudo isto pior era” J: "o pior era";

6.34) t. I, cap. XXII, p. 138: "lembrança que tive; do pedaço" J: "lembrança que tive: do pedaço";

6.35) t. II, cap. I, p. 8: "já lhe disse que é preciso ajudar a natureza. Passou-se ainda algum tempo." J: "a natureza. [§] Passou-se ainda" [encerradas as falas das personagens, o narrador normalmente retoma a palavra em outro parágrafo];

6.36) t. II, cap. II, p. 12: "e, apesar de gastar muito tempo nos deveres do ofício e na igreja, sempre lhe sobrara algum para empregar em outras coisas." J: "sempre the sobrava algum";

6.37) t. II, cap. II, p. 13: "e embebido em suas orações não estava à lerta," J: "não estava alerta," ["à lerta" talvez seja um ensaio de arcaísmo, na linha de "haveria morrer", muito embora tal forma não seja registrada em nenhum dicionário etimológico];

6.38) t. II, cap. III, p. 19: "tanto do seu físico como do seu moral. Seus contornos começavam-se a redondar-se" J: "a arredondarse" [não há registro, em dicionários modernos ou antigos, do verbo "redondar", ainda que, no caso, seja bastante eufônico - quem sabe uma tentativa de neologismo ou uma concessão à oralidade; de qualquer modo, optou-se por "arredondar-se"]; 
6.39) t. II, cap. III, p. 20: "que o sol o iluminava de dia, que se recamava de estrelas à noite." J: "de dia, e que se";

6.39a) t. II, cap. IV, p. 24: "Entre essas umas havia” J: "Entre essas uma havia" [cf. TM, p. 93];

6.40) t. II, cap. V, p. 30: “o compadre deu alma a Deus.” J: “deu a alma a Deus.";;

6.41) t. II, cap. V, p. 33-4: "Entregues alguns legados de pouca monta, etc., tudo o mais veio a cair nas mãos do Leonardo Pataca como herança de seu filho." J: "Entregues alguns legados de pouca monta, como fossem um crucifixo à comadre, um oratório a D. Maria e uma caixa de prata para rapé a um velho amigo do compadre, etc., tudo o mais veio a cair nas mãos" [a expressão "etc." só se usa, no texto, após enumeração. Nesse passo, há duas possibilidades: ou se resolveu eliminar os objetos, deixando-se, por equívoco, de riscar nos originais a expressão "etc.", ou foi, de fato, "pulo" durante a composição. Na dúvida, preferiu-se manter integralmente a lição do jornal];

6.42) t. II, cap. V, p. 34: "O Leonardo Pataca, que era condescendente, esteve pelo caso, e reuniu-se desse modo à família toda." $\mathrm{J}$ : "reuniu-se desse modo a família toda." [trata-se de uma questão de lógica: a familia toda é que se reuniu, e não Leonardo Pataca que se reuniu a ela];

6.43) t. II, cap. V, p. 34: "afilhado: se pelo contrário" J: "afilhado; se";

6.44) t. II, cap. VI, p. 39: "respondeu com voz trêmula e intercortada:” J: "entrecortada:";

6.45) t. II, cap. VII, p. 44: "À vista daqueles restos de um jantar, que, se não parecia ter sido abundante, fez-lhe lembrar que saíra de casa na ocasião de pôr-se a mesa, deu-lhe então o estômago umas formidáveis badaladas." J: "À [A] vista daqueles restos de um jantar que, se não parecia ter sido delicado, parecia ao me-

Leia-se o que Terezinha Marinho afirma a respeito dessa ocorrência em sua edição crítica, cit., p. 95. 
nos ter sido abundante, fez-lhe lembrar que saíra de casa na ocasião de pôr-se a mesa, e o estômago deu-lhe então umas formidáveis badaladas." [Aqui, de novo, um dilema: a condicional, quanto ao apetite de Leonardo, se deveria à qualidade da comida, e não a sua quantidade; trata-se, possivelmente, de um erro de composição, talvez provocado pelo fato de "delicado" e "abundante" estarem precedidas da locução "ter sido". Outra hipótese é que se tenha tentado reescrever o trecho, a fim de que "o estômago" passasse a ser sujeito da oração principal; mas, mesmo nesse caso, deve ter ocorrido qualquer equívoco durante a composição. Na dúvida, manteve-se a lição do folhetim, que é mais condizente com o andamento da narrativa: note-se que, mais adiante, o narrador observa que Leonardo comeu "a barrete fora", o que só seria possivel se ainda houvesse comida abundante ${ }^{9}$;

9 Haveria, talvez, algum reparo ideológico, diga-se assim, à opção adotada: por meio de uma sutil alteração, não estaria o autor "denunciando a miséria do povo brasileiro"? Resposta: não. Primeiro, as personagens que fazem a "patuscada" (piquenique) não são propriamente miseráveis. Segundo, o próprio fato de não ser a comida lá "muito delicada" fala por si só: bastava aos "pobres" de então o não poder banquetear-se nos locais chiques da época, onde a comida era abundante e delicada, com certeza: "Cristãos do século das luzes! se quereis proibir aos pobres que não entrem a casa onde banqueteais, ide para o Pharoux ou para o Ângelo, e aí podereis soltar gritos de alegria, palavras sem nexo; podeis esquentar os cérebros, pedir um voto, um empenho para um emprego rendoso, embora no santo ócio; podeis às largas curar das vossas conquistas, aprazar ali as entrevistas, consumar os atos nefandos de que muita gente hoje se ufana, porque, dói o dizê-lo [sic], ser motor de muitas lágrimas, cuspir a desonra na face da donzela, é moda sem a qual o homem que tem alguma coisa passa por estúpido!/ Oh! bem haja a estupidez assim entendida!/ Oh! mal haja a civilização como hoje se entende!" ("Pacotilha”, 04/07/1852, p. 1). Terceiro, tanto nas Memórias como na "Pacotilha" a preocupação era com a ignorância, e não com a miséria. Para enriquecer a discussão sobre o enfoque da fome entre os escritores do período, leia-se o seguinte trecho de José de Alencar, publicado em quatro de março de 1855 no mesmo Correio Mercantil, na seção "Ao Correr da Pena": "Uma coisa, por exemplo, de que ainda não vimos o governo se ocupar seriamente é a da carestia progressiva dos gêneros alimentícios, tanto nacionais como estrangeiros. 0 trigo está por um preço exorbitante, segundo dizem. 0 pão diminui, e diminui no século de progresso em que tudo vai em aumento, em que as menores coisas tomam proporções gigantescas. Quanto ao pão de rala, célebre em outros tempos, este desapareceu do mercado; pertence hoje à história./ Os ministros, os grandes, os ricos, não sabem disto; mas o pobre o sente, o pobre que, no meio de toda essa agitação monetária, de todo esse jogo de capitais avultados, vê as grandes fortunas crescerem e formarem-se, absorvendo seus pequenos recursos, e elevando os prę̧os dos gêneros de primeira necessidade a uma taxa quase fabulosa". Note-se como Alencar, agudíssimo, atribuía a carestia à especulação financeira, sua contemporânea; não seria o caso das Memórias. 
6.46) t. II, cap. VIII, p. 51: “-Ora... ora... disseram umas poucas de vezes. Além do costume” J: "poucas de vozes. [§] Além do costume" [cf. 6.35, supra];

6.46a) t. II, cap. VIII, p. 52: “É tarde não pode ser.” J: “É tarde, não pode ser.";

6.47) t. II, cap. IX, p. 56: "as raparigas parece que gostam mais da cambetice do que da reza." J: "mais da lambetice do que da reza." [provável erro de revisão; Terezinha Marinho também adotou a lição do jornal];

6.48) t. II, cap. IX, p. 59: "custou muito a vir, e abri-me aqui com ele. [§] E uma cousa the digo," J: "aqui com ele. E uma cousa" [a fala de uma mesma personagem não se divide em parágrafos];

6.49) t. II, cap. XI, p. 70: "Se esta facilidade de expansão não fosse acompanhada da grande dificuldade de rompimentos e de intrigas, seria uma das grandes virtudes daquele tempo." J: "não fosse acompanhada da grande facilidade" [essa opção, que já havia sido a de Darcy Damasceno, justifica-se por sua maior clareza. Caso a lição da primeira edição não seja erro de revisão, pode tratar-se da exploração literária do par antitético "facilidade/dificuldade", mediante o qual se força pouco mais ou menos a mão para que o sintagma "dificuldade de rompimentos e intrigas" seja interpretado como "dificuldades provocadas por rompimentos e intrigas"; do modo como ficou, porém, é quase inevitável que se entenda que os rompimentos e as intrigas ocorriam com dificuldade, justamente o contrário do que o texto quer dizer. Leia-se Terezinha Marinho, cit., p. 97];

6.50) t. II, cap. XII, p. 77: "Apenas cessou a bulha das carruagens, começaram estes últimos em conversa renhida, de que damos aqui uma pequena amostra." J: "pequena amostra:" [procedimento habitual no texto para introduzir fala de personagens];

6.51) t. II, cap. XII, p. 77: "Agora demos ao leitor algumas explicações" J: "Agora devemos ao leitor";

6.52) t. II, cap. XII, p. 79: "o Leonardo tinha abandonado Luisinha;" J: "o Leonardo tinha abandonado a Luisinha;" [o uso do artigo mantém o paralelismo com "o Leonardo"]; 
6.53) t. II, cap. XIV, p. 87: "de muito trabalho, fazer-me timido, respeitado por" J: "fazer-me temido," [timido, segundo Terezinha Marinho, pode indicar pronúncia; pode, eventualmente, indicar que a composição se fez sobre o manuscrito, com a leitura equivocada de "tímido" por temido];

6.54) t. II, cap. XXII, p. 137: “casa da D. Maria.” J: "casa de D. Maria.";

6.55) t. II, cap. XXII, p. 138: "veja o que me sucede” J: "veja o que lhe sucede";

6.56) t. II, cap. XXIII, p. 144: “-D. Maria que o diga, acudiu logo a comadre referindo-se a Maria Regalada, e querendo fazer brecha por onde fosse: mas não importa; o negócio é outro..." J: "por onde fosse; mas não importa;";

6.57) t. II, cap. XXIV, p. 150: "A comadre, informada de tudo, compareceu pesarosa a prestar seus bons ofícios, suas consolações. $[\S]$ O enterro saiu acompanhado" J: "suas consolações. $[\S]$ Mais tarde, disse ela depois de algum tempo de conversação, há de vir alguém cumprir dois deveres. [§] E limitou-se a isso sem mais se explicar. $[\S]$ O enterro" $[0$ trecho foi pulado durante a composição, constatação que se torna óbvia quando se lê na mesma página, mais abaixo, "Como havia prometido a comadre, alguém chegou quase ao anoitecer". Esse tipo de elipse não ocorre em nenhuma outra passagem do texto];

6.57a) t. II, cap. XXV, p. 156: "idéia lembrava-se" J: "idéia, lembrava-se";

6.58) t. II, cap. XXV, p. 159: "um era a sua baixa de tropa de linha;" J: "baixa da tropa de linha;".

7) Foram operadas, sem que se pudesse recorrer diretamente à lição do jornal, as seguintes retificações no texto (a emenda está entre colchetes):

7.0) t. I, cap. II, p. 18: "pela Maria; a fim de fazê-la" [Maria, a fim]. J: "pela Maria, para fazê-la"; 
7.1) t. I, cap. IV, p. 28: "tinha isso por causa contrariedades que sofria" [por causa de contrariedades]. Erro óbvio;

7.2) t. I, cap. IV, p. 28: "a rapariga tinha-lhe já feito umas poucas, e acabava também por fugir-lhe de casa.” [e acabara também]. Neste caso, nada -nem sequer a linguagem coloquial- justifica o uso do imperfeito; nos manuscritos da época, seria fácil confundir o " $v$ " com o " $r$ ";

7.3) t. I, cap. V, p. 33: "em cujas mãos se viam a arma de que acima falamos." [se via a arma]. A lição de J [em cujas mãos reluziam os competentes camarões] indica que, na redação original, a concordância estava correta. Esse é mais um indício de que a revisão para a edição em livro foi feita de forma apressada;

7.4) t. I, cap. XIII, p. 82: "hei de ir adiante com a coisa. Foi em consequiência" [abriu-se parágrafo, pois se trata do fim da fala da personagem e retomada da fala pelo narrador];

7.5) t. I, cap. XXI, p. 131: "um testamento falso que atribuíram ao Lourenço da Cunha, que, em abono da verdade, era bem capaz disso, pois era sujeito de mãos limpas.” [pois não era sujeito de]. O não é exigido pelo contexto, uma vez que, nessa passagem, José Manuel está falando mal de Lourenço da Cunha e de todo mundo;

7.6) t. II, cap. II, p. 13: "todos tinham visto entregue fervorosamente as suas súplicas a Deus." [fervorosamente às suas súplicas]. Em J: "fervorosamente às orações.";

7.7) t. II, cap. III, p. 19: "A comadre estremeceu temendo que D. Maria não desse com a língua nos dentes," [D. Maria desse com]. 0 contexto exige a supressão do "não";

7.8) t. II, cap. IV, p. 27: "que era para ela a pedra e escândalo contra José Manuel.” [a pedra de escândalo]. Modificação realizada por sugestão de Terezinha Marinho ${ }^{10}$;

7.9) t. II, cap. V, p. 31: "Continuaram as mais no seu coro de pranto dirigidos pela comadre;" [dirigido pela]. 0 coro é que é

10 Acerca dessa expressão, cf. Magalhães Jr., Raimundo. Dicionário Brasileiro de Provérbios, Locuções e Ditos Curiosos. Rio de Janeiro, Ed. Documentário, 1974, p. 245. 
dirigido pela comadre; em J: "Continuaram os mais", com base no qual se poderia também propor "dirigidas";

7.10) t. II, cap. XII, p. 76: “desfazia-se em mesuras à D. Maria.” [a D. Maria.]. Questão de coerência: D. Maria não é precedida de artigo em nenhuma outra passagem do texto; em J: "para D. Maria.";

7.11) t. II, cap. XIII, p. 82: "um transe a que assemelhava, aquele em que então se achava," [assemelhava aquele]. A redação de J ["um transe a que ele assemelhava o em que se achava"] indica que, ao se tentar melhorar a redação do original, a vírgula acabou por assim dizer "sobrando" - ou, então, foi fruto de má leitura dos originais (certamente rabiscados) enviados à tipografia quando da composição em livro;

7.12) t. II, cap. XVI, p. 97: "manifestar este sentimento. A umas dálhe para chorar em um canto;" [A umas dá-lhes]. Em J: "sentimento: uma dá-lhe";

7.13) t. II, cap. XVI, p. 98: "de maneira a deixar na cabeça do mísero que a escuta uma asuada eterna," [uma assuada]. Terezinha Marinho informa que haveria cruzamento semântico entre "assuada" e "azuada" (azoada em grafia moderna), embora no texto já tivesse ocorrido a grafia "azuou". No supracitado dicionário de Morais, registra-se "assoar” (p. 213. v. I), "assoada” (p. 212), “assuar” (p. 216) e "assuada” (p. 215), mas não "azoar" nem "azuar” (e sim "zoar"). Confira-se o dicionário de Antônio Maria do Couto, que registra confusão entre "assuada" (barulho, gritaria) e "asoada" (ato de assoar o nariz) ${ }^{11}$. Tampouco no dicionário atribuído a Domingos Vieira se registra confusão entre "assuada" e "azoada". Portanto, o termo deve atualizar-se, sem sombra de dúvida, como "assuada";

7.13a) t. II, cap. XIX, p. 117: “cantigas § Papai” [cantigas - § Papai]. J: "cantigas - Papai";

7.14) t. II, cap. XXI, p. 131: "concluiu que os planos haviam sortido bem, e que o major ficara” [surtido bem, e]. Esse pode ser, como

11 Dicionário da Maior Parte dos Termos Homônimos, e Equívocos da Língua Portuguesa. Lisboa, Tipografia de Antônio José da Rocha, 1842, p. 16. Quem consultar esse trabalho não deixará de notar que ali não se respeita a ordem alfabética. 
afirma Terezinha Marinho, um caso de cruzamento semântico entre "sortir" e "surtir". Mais do que isso: conforme os citados dicionários de Morais (v. 2, p. 726), de Antônio Maria do Couto (p. 726) e de Domingos Vieira (v. 5, p. 596), os verbos que atualmente se grafam "sortir" $e$ "surtir" teriam a mesma grafia: "sortir". 0 assunto era controverso: segundo D. Vieira (v. 5, p. 638), "surtir", relacionada com "surto", significa "voar alto, remontar-se"; já Couto pondera que "surtir", "do Latim surgere", significa, além de voar alto, "entrar no porto". São informações hoje consideradas impróprias ${ }^{12}$;

7.15) t. II, cap. XXIII, p. 144: "Contudo, posto que a comadre soubesse já desta circunstância com antecipação, ou o pressentisse pelas aparências," [ou a pressentisse]. Em J: "soubesse disso com antecipação, ou o pressentisse". Parece óbvio que, na troca de "disso" por "desta circunstância", esqueceu ao autor corrigir o pronome;

7.16) t. II, cap. XXIII, p. 145: “-Pois é mesmo por me lembrar destas feridas antigas, atalhou a Maria Regalada que venho aqui” [a Maria Regalada, que venho];

7.17) t. II, cap. XXIII, p. 148: “-Ora, graças que se lhe acabaram os sestros, respondeu Maria Regalada em voz alta:” [em voz alta.]. Em J não há sinal de pontuação após a última palavra; como a ocorrência é única, optou-se, com Terezinha Marinho, pela substituição dos dois pontos pelo ponto final;

7.18) t. II, cap. XXIV, p. 152: "por muito tempo trabalhava," [trabalhara,]. Cf. 6.18 e 7.2 ;

7.19) t. II, cap. XXV, p. 155: "rosário vinha-lhe" [rosário, vinhalhe]. J: "rosário, lhe vinha";

8) Mantiveram-se, enfim, as seguintes passagens (consignadas também em J), que em outras edições foram alvo de modificações ou reparos:

12 Cf.: Amaral, Vasco Botelho do. Dicionário de Dificuldades da Língua Portuguesa. Porto, Educação Nacional, 1938, v. 2, p. 333; e Almeida, Napoleão Mendes de, op. cit., p. 532. 
8.1) t. I, cap. I, p. 6: "era a influência que derivavam de suas condições físicas." (o sujeito de "derivavam" é "meirinhos"; o verbo "derivar", como não se deveria ignorar, pode significar também "fazer derivar", construindo-se "derivar algo de algo": os meirinhos derivavam sua influência de suas condições fisicas ${ }^{13}$ );

8.2) t. I, cap. I, p. 8: "saloia rochonchuda e bonitota.";

8.3) t. I, cap. V, p. 35: "Aí esteve o Leonardo o resto da noite e grande parte da manhã, exposto à vestoria dos curiosos." (manteve-se vestoria por ser forma coloquial de vistoria ${ }^{14}$; também ocorre duas vezes no mesmo tomo I, cap. XVI, p. 101);

8.4) t. I, cap. VI, p. 40: "traziam toilletes de toda a casta,";

8.5) t. I, cap. VII, p. 43: "Era a comadre uma mulher baixa, excessivamente gorda, bonanchona," (forma coloquial de bonachona);

8.6) t. I, cap. XIII, p. 83: "o outro com a tocha despejava-lhe sobre as costas da mantilha a cada passo plastradas de cera derretida," (manteve-se plastradas, deformação de plastadas);

8.7) t. I, cap. XIV, p. 89: “O orador começou: falava já a um quarto de hora sem que". Preferiu-se manter essa passagem, que pode ser um arcaísmo, conforme se afirma logo na página 1 do dicionário de Antônio Moraes e Silva ${ }^{15}$, muito usado no Brasil - com orgulho, digase, de muitos letrados brasileiros, pois brasileiro era seu autor. Confirase ainda o que se afirma em Terezinha Marinho, cit., p. 94;

8.8) t. I, cap. XV, p. 98: "estava com efeito a mais de meia hora”. Cf. item anterior;

8.9) t. I, cap. XVI, p. 103: "A comadre tinha uma sobrinha que vivia" (a partir do t. II, a "sobrinha" torna-se "filha" e recebe um nome

13 Cf. Fernandes, Francisco. Dicionário de Verbos e Regimes. Rio de Janeiro/São Paulo/Porto Alegre, 1959, p. 189; e Luft, Celso Pedro. Dicionário Prático de Regência Verbal. São Paulo, Ática, 1996, p. 173-174.

14 No dicionário de Moraes, que registra tanto "vistoria" (cit., t. Il, p. 859) como "vestoria”, faz-se, quanto à segunda forma, a seguinte ressalva: "V. Vistoria, como a gente polida pronuncia" (idem, p. 848).

15 "A por há do verbo Haver acha-se nos documentos antigos" (op.cit., p. 1) 
- ou melhor, dois nomes: no jornal, Mariquinhas; no livro, Chiquinha; manteve-se todavia o equívoco por, talvez, indicar o objetivo inicial do autor de traçar um paralelo entre as vidas dos dois Leonardos, o pai e o filho; ambos se envolveriam com sobrinhas: o filho, com a de D. Maria, e o pai, com a da comadre. Depois, o plano foi abandonado, mas a incongruência permaneceu ali, como uma espécie de resquício recalcitrante);

8.10) t. I, cap. XVIII, p. 116: "A comadre tinha conseguido o seu fim, pelo que diz respeito à sobrinha; tanto fizera" (cf. item anterior);

8.11) t. I, cap. XIX, p. 120: "saíam pelas ruas da cidade um rancho de meninos," (silepse mantida);

8.12) t. I, cap. XXII, p. 136: "pois está de cor o tal sujeito:” (essa expressão não encontra abrigo em dicionário algum. Trata-se de coloquialismo com o sentido de "está querendo aborrecer", conforme registra o escritor José Antônio, contemporâneo de Almeida) ${ }^{16}$;

8.13) t. II, cap. I, p. 9: "venha ver a sua pecurrucha... [§] - É uma pecurrucha!..." (conforme diz Terezinha Marinho, é expressão encontradiça em outros autores do período);

8.14) t. II, cap. VI, p 39: "Ah bom côvado e meio! atalhou Chiquinha, ah bordo da nau!... ah major Vidigal!... (embora as edições críticas, e com elas as edições escolares, tenham botado um ponto de exclamação após cada interjeição, a lição de J [-Ah! bom côvado e meio, atalhou Mariquinhas, ah! bordo da nau!... ah! major Vidigal!...] indica que o trecho foi "repontuado", diga-se assim, para a edição em livro; trata-se de um exercício de economia expressiva que deve ser mantido - note-se, v.g., o critério, que aí obedece a um princípio de paralelismo, de deslocar o ponto de exclamação para o final de cada uma das afirmações de Chiquinha-Mariquinhas);

8.15) t. II, cap. VI, p. 40: "Com isto o Leonardo Pataca desacoroçoou completamente;" ("desacoroçoou”, bem como "desacorçoou”, são formas coloquiais de "descoroçoou”);

16 Silva, José Antônio Frederico da. "Reta pronúncia na história de uma velha”. In Lembranças de José Antônio. São Paulo, Giordano, 1991, p. 171 (1. ed. de 1858). 
8.16) t. II, cap. VI, p. 41: “-Porém ia-lhe saindo cara desta vez, acudiu Leonardo Pataca." "“cara" foi mantido por apresentar concordância ideológica com "foi uma das costumadas do afilhado dos seus amores", na fala anterior);

8.16a) t. II, cap. VIII, p. 52: “José Manuel fora o primeiro;”;

8.17) t. II, cap. XIII, p. 84: "porém tendo esta atirado três ou quatro ditos fortes de mais aos primos,";

8.18) t. II, cap. XIV, p. 87: "vir um melquetrefezinho pôr-me sal";

8.19) t. II, cap. XV, p. 93: "por entre muita praga e esconjúrio";

8.20) t. II, cap. XVII, p. 104: "A surpresa, e mesmo também a figura de Vidinha, decomposta pela raiva," (manteve-se "decomposta"; a lição de J [cujos traços, decompostos pela raiva,] diminui a possibilidade de erro de revisão, pois, ao reescrever o trecho, o autor manteve o adjetivo).

9) Registre-se, enfim, que muitos dos problemas levantados pelas Memórias de um Sargento de Milícias provêm dos coloquialismos de que o texto lança mão. Assim, por exemplo, com o caso da expressão "côvado e meio às costas", que significava farda do exército ou da polícia, e não "uma espécie de bastão para dar pancadas"17. Outro caso é o do verbo "surdir", utilizado por mais de uma vez no texto, e cujo sentido não apresenta dúvidas; o

17 A expressão é consignada como regionalismo pernambucano e potiguar, como se vê no Vocabulário Pernambucano de F. A. Pereira da Costa: "farda de soldado: o rapaz está perdido; preguem-lhe o côvado e meio às costas" (Recife, Secretaria da Educação e Cultura, 1976, p. 275), e no Calepino Potiguar de Raimundo Nonato: "nome antigo da farda dos soldados, porque eram muito curtas" (Coleção Mossorense do Senado Federal, v. CXIX, Brasília, 1980, p. 133). A definição de "côvado e meio" como bastão para dar pancadas é do padre Carlos Teschauer no Novo Dicionário Nacional (Porto Alegre, Globo, 1928, p. 250), que cita como abonação o próprio texto das Memórias. O equívoco fica evidente, porém, quando se lê, no capítulo XI, tomo I, p. 68, o seguinte: "[a vizinha] não perdia ocasião de desmentir o vizinho em suas esperanças a respeito do afilhado, declarando que não lhe via jeito para coisa nenhuma, que não queria para coisa que lhe pertencesse o fim que ele havia ter, e que quando ele crescesse o melhor remédio era dar-lhe com os ossos a bordo de um navio ou pôr-lhe o côvado e meio às costas". 
JAROUCHE, Mamede Mustafa. A propósito de uma nova edição das Memórias de um Sargento de Milícias.

curioso, porém, é que a palavra se tomava, naquele período, como gíria de capadócios ${ }^{18}$.

ABSTRACT: This article explains the criteria of the textual fixation of a new edition of $\mathrm{Me}$ mórias de um sargento de milícias. There are only two texts to compare: the serial publication and a single book form published during the author's life. The serial publication was given priority, especially when the $1^{\text {st }}$ edition seemed doubtful.

Keywords: Memórias de um Sargento de Milícias, critical edition, nineteeth century, Brazilian romantic literature, Manuel Antônio de Almeida.

18 Conforme se registra na "Carta de um capadócio a outro seu amigo". In Lembranças de José Antônio, op. cit., p. 155. 